\title{
IL-9: Function, Sources, and Detection
}

\section{Wilmer Gerardo Rojas-Zuleta and Elizabeth Sanchez}

\begin{abstract}
IL-9 is a pleiotropic cytokine produced in different amounts by a wide variety of cells including mast cells, NKT cells, Th2, Th17, Treg, ILC2, and Th9 cells. Th9 cells are considered to be the main CD4+ T cells that produce IL-9. IL-9 exerts its effects on multiple types of cells and different tissues. To date, its main role has been found in the immune responses against parasites and pathogenesis of allergic diseases such as asthma and bronchial hyperreactivity. Additionally, it induces the proliferation of hematologic neoplasias, including Hodgkin's lymphoma in humans. However, IL-9 also has antitumor properties in solid tumors such as melanoma. The objective of this review is to describe IL-9, its function, sources, and methods of detection.
\end{abstract}

Key words Interleukin-9, P 40, T Lymphocyte growth factor, Mast cell growth-enhancing activity, Th9 cells

\section{Introduction}

Interleukin-9 (IL-9) is a pleiotropic cytokine produced in varying amounts in different immune cells. Among these are mast cells, NKT cells, Th2, Th17, Treg cells, and Th9 cells, with the greatest amount being produced by the latter [1]. It is a $14-\mathrm{kD}$ glycoprotein, which is composed of 144 amino acids and one signal peptide of 18 amino acids [2]. The human IL-9 gene is located on the long arm of chromosome 5 . It is found in the Th2 cytokine gene cluster [3]. In murine, it is localized in the chromosome 13 and is not linked to the same gene cluster [4]. The human IL9 gene has promoter sequences to transcription factors such as PU.1 and IRF4, among others that regulate their expression $[5,6]$.

IL-9 receptor is a part of the cytokine family that share the common $\gamma$ chain receptor, including IL-2, IL-4, IL-7, IL-15, and IL-21 [7]. IL-9 receptor is made up of IL-9R $\alpha$ apart from the common $\gamma$ chain. When IL-9 binds to its cognate receptor, it recruits Janus Kinase 1 (JAKl) and JAK 3 to $\alpha$ and $\gamma$ chains, respectively [8]. These are cross-phosphorylated and activate STAT family of transcription 


\subsection{Discovery}

factors STAT1, STAT3, and STAT5, which form either homodimers or heterodimers. Afterwards, they move to the nucleus to activate the expression of IL-9-induced genes [1].

IL-9 was first described in $1989[1,9]$. Initially discovered in cell clones (TUC2 and TUC7) derived from C57BL/6 mice immunized with concanavalin A, the supernatant of these cell lines was observed to support the growth of specific $\mathrm{T}$ helper cell clones in the absence of other stimulus [10]. This supernatant was purified and this $\mathrm{T}$ cell growth factor was originally called $\mathrm{P} 40$, T lymphocyte growth factor (TCGFIII) or MEA (mast cell growth-enhancing activity). At first, it was thought to be part of a cytokine repertoire produced by Th2 cells. Nevertheless, it was not known if it was produced by IL-4-producing Th2 cells [11] or if it was secreted by another other immune cells [12].

In 1994, Schmitt et al. [13] for the first time described the IL-9 production by naïve CD4+ murine effector lymphocytes in presence of IL-2 along with TGF- $\beta$. Likewise, they found that adding IL-4 enhanced this effect. These cytokines acted synergistically and had a dose-dependent effect to induce IL-9. In contrast, when IFN- $\gamma$ was added to the medium with TGF- $\beta$, IL-9 secretion was inhibited. Schmitt et al. also proposed that the synergistic effect of IL-4 in IL-9 production is secondary to its capacity to inhibit IFN- $\gamma$ production. Thus, the inhibiting effect it has on the IL-9 expression is neutralized [13].

Later on, studies by Veldhoen et al. showed that IL-4 producing Th 2 cells cultured in the presence of TGF- $\beta$ would stimulate production of IL-9 [14]. Dardalhon et al. also demonstrated that with the stimulus of IL- 4 and TGF- $\beta$ on a specific T cell subset would subsequently promote the differentiation to polarized cells that would produce high quantities of IL- 9 as well as IL-10 in mice [15]. This study found that IL- 4 was able to suppress TGF- $\beta$ induced Foxp3 expression and prevent the generation of Foxp3 ${ }^{+}$ Treg cells, and promoted predominantly Foxp ${ }^{-} \mathrm{IL}^{+} \mathrm{IL}-10^{+} \mathrm{CD} 4^{+}$ $\mathrm{T}$ cells that did not suppress $\mathrm{T}$ cell responses $[14,15]$. These cells were termed as Th9 cells.

These findings sparked a renewed interest in IL-9 and its role in immune regulation as well as in IL-9-secreting other cells. Several studies have revealed other cellular sources of IL-9 [1]. Human Thl7 cells have been demonstrated to secrete concomitantly IL-9 and IL-17 under TGF- $\beta$ stimulation [16]. In addition to being the target of IL-9, activated mast cells have also been identified as IL-9 producers [17]. Natural killer T cells are also capable of producing IL-9, initially observed in $\mathrm{DX}^{+} \mathrm{CD}^{+} \mathrm{T}-\mathrm{NK}$ cells derived from murine splenocytes [18], but later was observed in human nasal NKT lymphoma cells [19]. And while Treg cells have been shown to produce IL-9, to date, debate persists regarding the in vivo conditions this occurs [16]. New research is 


\subsection{Function}

1.2.1 Allergic Inflammatory Processes currently focusing on discovering different factors involved in influencing IL-9 production in different cells and the multiple effects that this cytokine exerts.

IL-9 exerts its effect on multiple types of cells and different tissues (Fig. 1), and initially was considered as a growth factor of activated $\mathrm{T}$ cells [20]. Later, its potent proliferative effects were demonstrated in other cell types mainly mast cells [21], hematopoietic erythroid precursors and on myeloid leukemia cell lines [22].

IL-9 plays an important role in the regulation of airway inflammation and airway hyperresponsiveness. IL-9 transgenic mice develop an asthma like phenotype and lymphocytic and eosinophilic lung inflammation [23]. It has been demonstrated that IL-9 exerts proliferative effects on goblet cells and cells that produce mucin in the airways [24], which is reflected with an increased production of mucus, favoring allergic inflammation in the respiratory tracts [23]. However, increased Th9 cell numbers in peripheral blood of allergic patients correlated with $\operatorname{IgE}$ titers [25]. In B lymphocytes, IL-9 in the presence of IL- 4 increases secretion of IgGl and IgE and it also promotes an isotype switch [23], contributing to the pathogenesis of allergic diseases of the respiratory tract, specifically in asthma and bronchial hyperreactivity [26]. The pathogenic role

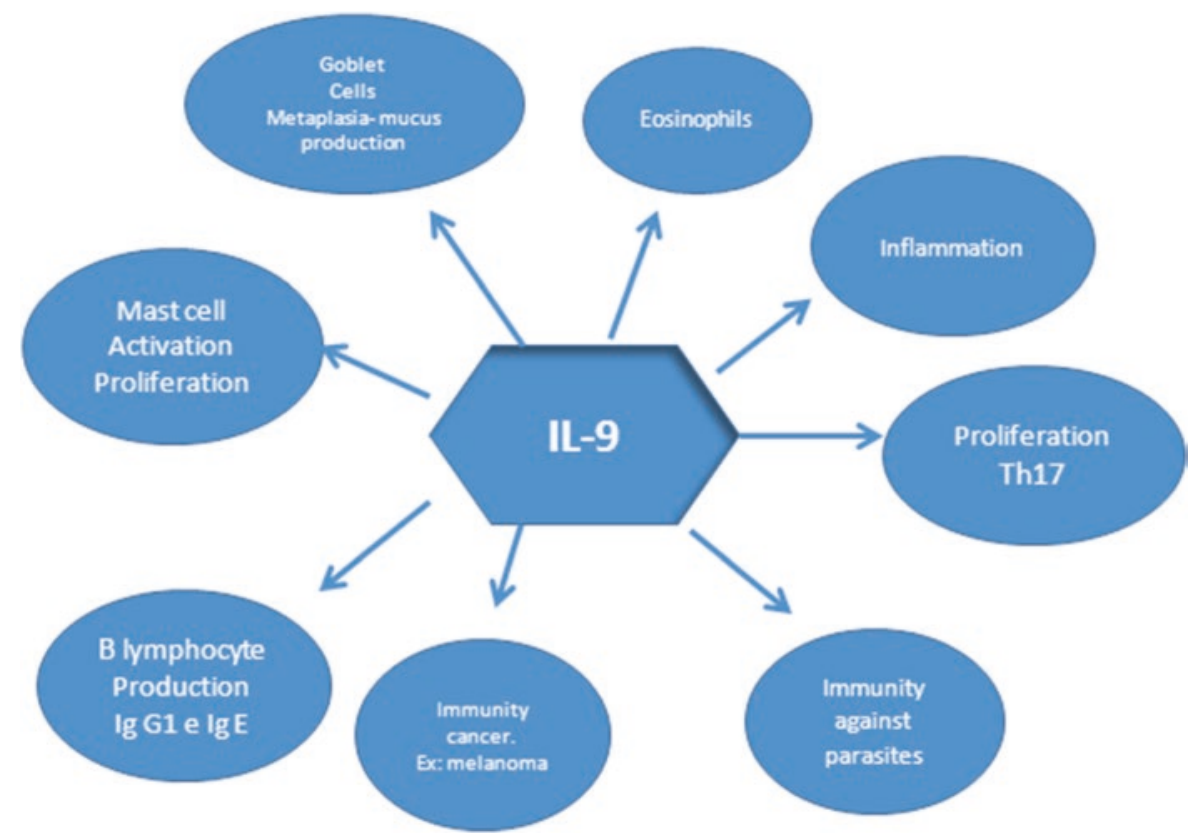

Fig. 1 Functions of interleukin-9. IL-9 participates in a great variety of physiological processes ranging from promoting inflammatory mechanisms up to immunity against parasites and tumors. Nevertheless, because of its effects on the activation of mast cells, eosinophils and the induction of IgE production, just like the production of mucus by goblet cells, it participates in the pathogenesis of allergic diseases like asthma 


\subsubsection{Effect on Neoplasia}

1.2.3 Immunity Against Parasites

1.2.4 Anti-inflammatory Effects

1.2.5 Autoimmune Diseases of IL-9 in allergic diseases was demonstrated in a Rag2-/- murine model via the induction of allergic inflammation in airways mediated by ovalbumin and the adoptive transfer of Th9 cells. An induction of goblet cell metaplasia and an increase in bronchial reactivity was observed. These effects were reduced when an antiIL-9 monoclonal antibody was administered [27].

IL-9 has been demonstrated to play an important role immune regulation in neoplasia. Among these, one important aspect is related to hematologic neoplasms. In vitro studies have demonstrated that ectopic expression of IL-9 induces the proliferation of mouse thymic lymphomas. In humans, in vitro studies have observed increase of IL-9 production in cells of Hodgkin's lymphoma by promoting the growth of these cultured cells [8]. The effect of IL-9 in neoplasia may depend whether the tumor is solid or not. In solid tumors, specifically in melanoma, it has been demonstrated that Th9 and IL-9 have an important antitumor effect favoring the recruitment of both innate adaptive immune cells, reducing tumor burden [28].

In addition, it has also been shown that IL-9 participates in immunity against parasites. IL-9 transgenic mice overexpressing IL-9 eradicate Trichinella spiralis infections faster than wild-type mice [29]. This nematode requires a great amount of intestinal mast cells for its elimination. Nevertheless, $I L-9-/-$ mice did not show alterations in the development of $\mathrm{T}$ cells, in the antibody-mediated response or the clearance of the infection caused by Nippostrongylus brasiliensis, which suggests a high redundancy for IL-9 function and the intervention of other cell phenotypes, such as Th2 cells [30]. In this scenario, IL-9 participates as an important factor driving host protective immunity against parasites, promoting effective anti-helminth responses in vivo. Apart from Th9 cells, IL-9 might require help from cell types to mount an optimum anti-parasitic response.

Apart from inflammatory effects of IL-9, anti-inflammatory effects of the cytokine have been demonstrated to depend on the cell types expressing it as well as on the microenvironment in which it is produced. IL-9 secretion by Treg cells participates in the induction of tolerance [31]. It has been demonstrated that IL-9 stimulates the differentiation of non-allergic mast cells with the capability of inducing local tolerance during allogeneic skin transplants on mice. In contrast, neutralization of IL-9 via monoclonal antibodies promotes an accelerated rejection to skin allotransplants on previously tolerant mice [31]. This anti-inflammatory regulation demonstrates the important role IL-9 plays in immune tolerance.

IL-9 has been implicated in numerous pathogenic processes of diseases, mainly allergic diseases as asthma and atopic dermatitis [32]. IL-9 serum levels are elevated in patients with systemic lupus 
erythematosus [33], rheumatoid arthritis [34, 35] and systemic sclerosis [36] but their clinical significance are still not completely understood. It has been debated if IL-9 has a role in the pathogenesis of these diseases, or if its presence is due to an epiphenomenon caused by a broad activation of inflammatory mechanisms, and this has made it difficult to define its function in the development of the disease; thus further studies are required to elucidate the pathogenic role in those rheumatic disease $[37,38]$.

\subsection{Sources}

1.3.1 Th2 Cells

1.3.2 NKT Cells
As previously mentioned a variety of cells produce IL-9, in vivo studies are rare to assess the amount of IL-9 being produced. During the discovery of this cytokine, multiple studies have been able to discover the cells that express IL-9 and the stimulation that triggers this production.

As discussed earlier, when IL-9 was first discovered, Th2 cells were one of the first cells studied in association to this cytokine. As mentioned above, they were studied in murine models infected in vivo with Leishmania major and these cells were found to co-express other cytokines as well including IL-4, IL-5, and IL-13. Initially believed to be the main producers of IL-9, a correlation was found between Th2 cell expansion and IL-9 levels. Additionally, IL-4 stimulation was found to play a key role in Th2 cell differentiation and necessary for IL-9 production in these cells [39]. Further studies have demonstrated the co-expression of IL-4 and IL-9 in differentiated Th2 cells; however, these quantities are very low [40]. The discovery of other cell sources has revealed larger quantities of this cytokine originating from other cells, suggesting that Th2 cells are not the main producers of IL-9.

It has been demonstrated that under certain conditions, natural killer T (NKT) cells can produce IL-9. Studies using NKT cells from naive mice have shown that after stimulation with IL-2, these cells can produce IL-9 [18]. IL-2 stimulation also triggers the expression of IL-4, IL-5, and IL-13 in NKT cells, but not IFN- $\gamma$, suggesting that these cells assist in the humoral immune response [18]. Naïve NKT cells in the presence of TGF- $\beta$ and IL-4 polarize and secrete IL-9 in murine and human thymic iNKT cells [41]. Jones et al. observed that in the absence of CDId, pulmonary NKT cells decrease IL-9 expression accompanied by decrease in mast cell recruitment to the lungs in allergic airway inflammation [42]. Additionally, peripheral iNKT cells under the influence of TGF- $\beta$ and IL-4 adopt an IL-9-producing NKT cell phenotype able to mediate pro-inflammatory effects observed in vivo, namely granulocyte and mast cell recruitment to the lungs [41]. Other studies have also discovered that NKT cells that have been involved in nasal NKT cell lymphoma can also produce IL-9 that acts as an autocrine growth factor and promotes disease progression [19]. 
1.3.3 Mast Cells

1.3.4 Th9 Cells

1.3.5 Th17 Cells
It has also been discovered that activated mast cells can secrete IL-9. Several cytokines have been found to stimulate IL-9 production by mast cells, while IL-9 acts as a growth factor and promotes mast cell expansion [17]. Mast cells are stimulated in an autocrine manner in response to IL-9-induced signals and the cross-linking of $\mathrm{IgE}$ molecules on the surface of mast cells triggers release of numerous other cytokines $[17,43]$. Histamine and IL-1 $\beta$, two cytokines released after mast cell degranulation, have been found to further IL-9 production, and along with IL-9 itself, seem to behave in a positive feedback loop inducing IL-9 production [43]. Mast cells have been observed to produce IL-9 in response in a p38 MAPKdependent manner, and the activation of GATAl has been found to increase $I 19$ promoter activation [44]. Wiener et al. found that IL-9 production in conjunction with ionomycin can trigger the expression at mRNA level of Il4, Il5, Il9, IllO, Ill $\beta, I l 1 r a, I l 6$, and MIF [43]. In addition, IL-9 can induce mast cell production of proinflammatory factors, such as IL-1 $\alpha$, IL-1 $\beta$, IL-1R $\alpha$, IL-3, IL-4, IL-5, and IL-6, which is believed to contribute to airway hyperresponsiveness [43]. Chen et al. has recently discovered multifunctional IL-9-producing mucosal mast cells in mice in intestinal mucosa [45]. Intestinal mucosal mast cell production of IL-9 and IL-13 could also play a role in the development of food allergies in mice [45]. Further studies are needed to determine the importance of mast cell IL-9 production in development of food allergies.

In 2008, Veldhoen et al. [14] discovered a distinct CD4 ${ }^{+} \mathrm{T}$ subpopulation based on the cultivating $\mathrm{CD}^{+}$murine lymphocytes under different groups of inductor cytokines which polarized the differentiation toward Th1, Th2, Th17, Treg, and CD4+ IL-9+ cells. There was evidence that these cells, which acquired the IL-9 phenotype lost expression of other characteristic cytokine of $\mathrm{T}$ effector lymphocytes including IL-4, IL-5, IL-13 (Th2), IL-17- $\alpha$ (Th17), or IFN- $\gamma$ (Thl), and they expressed very low level of transcription factors T-bet for Th1 [46], GATA3 for Th2 [47], Foxp3 for Treg [48], and RORyt for Thl7 cells [49]. This suggested that this subset of lymphocytes is a different T-lymphocyte subpopulation characterized by the expression and secretion high amounts IL-9 and IL-10 and hence they were named Th9 lymphocytes. To date, a wide variety of stimuli has been described which contribute to Th9 cell differentiation, as IL-2 [13], IL-25 [50], the peptide related to the calcitonin gene [51], and thymic stromal lymphopoietin [52], among others. This redundancy suggests cell function diversity and heterogeneity.

Studies have demonstrated that polarized mouse Th17 cells can produce IL-9 while co-expressing IL-17 as well [16]. However, IL-23 has been observed to suppress IL-9 production and given its importance in the maintenance of Th17 cells it remains unclear 


\subsubsection{Treg Cells}

1.3.7 ILC2 Cells

\subsection{Detection}

whether this IL-9 production by Thl7 cells is transient [53]. In vitro studies have shown that human Th17 cells also produce IL-9. Differentiated naïve cells need repeated stimulation by Th17 inducing conditions to co-express IL-17 and IL-9. Memory CD4 ${ }^{+}$ $\mathrm{T}$ cells subjected to Th17 inducing cytokines such as IL-1 $\beta$ and IL-21 result in the co-expression of IL-9 and IL-17 [16].

Few studies have suggested the production of IL-9 by Treg cells. While a couple of studies have confirmed that IL-9 is produced by Treg cells, there are conflicting reports under the circumstances which this occurs $[1,12,31]$. One study reported co-expression of forkhead box P3 (Foxp3) and IL-9 in Treg cells in tolerant murine allografts [31]. This has not been reported in other studies, which studied the function of Treg cells in vitro [54]. Additionally, in human donors the co-expression of Foxp3 and IL-9 has not been reported either [16]. Further studies are needed to explore the role of IL-9 production in Treg cells and their role in immune regulation in humans.

Research has discovered a novel subset of innate lymphoid cells (ILC) that release type 2 cytokines named group 2 ILC (ILC2) cells [55]. Studies with IL-9 reporter mice in vivo have demonstrated that in certain inflammatory milieu, ILC2 cells have been found to express IL-9 cells to variety of stimuli [56-58]. In a papain-induced lung inflammation model in mice, Wilhelm et al. discovered that IL-9 was largely produced by ILC2 cells. This production was demonstrated to be dependent on IL-2, but rapidly diminished as other the production of other cytokines, such as IL-13 and IL-5 increased [56]. When IL-9 production was neutralized in ILC2 cells, a lower expression in IL-13 and IL-5 was observed, suggesting that the production of IL-9 by ILC2 cells may play a role in regulation of Th2 cells [56]. Another study in IL-9R-deficient mice demonstrated that ILC2 expression of IL-9R was important in the production of IL-5 and IL-13 in infection with Nippostrongylus brasiliensis in the lung [59]. The absence of IL-9 signaling in these mice resulted in reduced lung ILC2 recruitment and suggests that the production of IL-9 works as an autocrine amplifier in the function and survival of ILC2 cells [59]. IL-9 production in ILC2 cells seems to be dependent on other cytokine stimulation and play a role in immune response in the lung.

Finally, depending on the environment in which one wants to quantify either fluid or tissue there are several methods for detecting IL-9. Current methods for quantitative IL-9 detection in serum, plasma and cell culture include ELISA and proliferation assays and tissue or cell expression can be detected through quantitative real-time PCR for $I 19$ mRNA expression. 
1.4.1 ELISA

1.4.2 Quantitative Real-Time PCR

1.4.3 Proliferation Assays
Presently, ELISA kits for IL-9 are widely commercially available and have been used in various studies for quantification of IL-9 levels in serum, plasma and supernatant samples. Various manufacturers have developed ELISA kits that use sandwich ELISA technique measuring IL-9 between capture and detection antibody. These ELISA kits utilize both human and mouse antibodies. The methodology to carry out the ELISA depends on the manufacturer's instructions, which vary between commercial houses. To date there have been no studies comparing performance between these different ELISA kits ( see Note 1).

Quantitative real-time reverse transcription followed by polymerase chain reaction (RT-PCR) is the most appropriate method for the detection and quantification of cytokine mRNA quantification [60]. It enables quantification of nucleic acids through amplification in a cyclic process (high temperature-low temperature) that generates a large amount of identical copies of the sequence to be analyzed. For analysis of $I l 9$ expression, isolating mRNA from the plasma or supernatant sample that is initially required and cDNA is transcribed using a reverse transcriptase. In this case, the reverse transcriptase utilized is a specific mRNA transcript Il9 hybridizing polyA tail to the mRNA ( $3^{\prime}$-end). The amount of amplified product is monitored during the course of the reaction by measuring the fluorescence (through labeled primers), which is proportional to the amount of product formed [61]. For quantitative analysis, it is necessary to perform a normalization process to compensate for differences between the amounts of biological material samples each. This will be done by comparing the result with the relative expression of a gene known constant expression (e.g., $\beta$-catenin) by using the $2-\Delta \Delta C$ t method [62]. This method is highly sensitive and specific, has good reproducibility and wide range quantification, which makes the method of choice for quantifying the expression of multiple cytokines.

Proliferation assays act as alternative method to detect IL-9 through the capacity of IL-9 to induce proliferation certain cellular lines. Several cell lines that can be used for this purpose. Here we describe two cellular lines that are predominantly used (see Note 2 ).

TS1h9RA3 (TS1) is a murine cell line transfected with a human IL-9 receptor commonly used in proliferation assays [10]. These cells are receptive to stimulation murine IL-4, human IL-9 or murine IL-9. These cells are cultured in a serial dilution of known IL-9 concentrations. Then their growth or proliferation can be measured through hexosaminidase method or $[3 \mathrm{H}]$ thymidine incorporation [63]. In the latter, the determination of cell proliferation is assessed by measuring the incorporation of $[3 \mathrm{H}]$ thymidine into cellular DNA [64]. This radioactive label is added during the last 4-24 h of the culture. The harvest of the cultures is carried 
out with a semi-automated cell harvesting apparatus. This will lyse the cells with water and precipitate the labeled DNA on glass fiber filters. After these filters are dried, they are counted by standard liquid scintillation counting techniques in a $\beta$ counter [64].

Furthermore, this method has the advantage that only human IL-9 is able to promote proliferation, which makes it ideal in a medium with several cytokines present simultaneously. Nonetheless, one of the major disadvantages of this method is that in a medium with high cell density and low availability of IL-9, this effect is no longer observed in cell growth.

The M-O7e cells are human megakaryoblastic leukemia cellular line dependent on IL-3 or granulocyte macrophage colonystimulating factor for proliferation. Other factors such as human IL-2, IL-4, IL-6 and murine or human IL-9 also stimulate the growth of these cells [65]. These cells are grown in different known dilutions of IL-9 and these known concentrations are subsequently compared to the growth that results using the sample with the unknown concentration of IL-9 and the amount of $[3 \mathrm{H}]$ thymidine that is incorporated into the cells. They have the disadvantage of requiring cytokine free medium so that there is no interference in the measurement of IL-9, since these cells can proliferate in the presence of other cytokines ( see Note 3 ). Therefore, this is not a useful tool when measuring IL-9 in a medium that has other cytokines. In the following section we describe the method of IL-9 proliferation assay.

\section{Materials}

The use of these materials has been described by Jean-Christophe Renauld and Jacques Van Snick and included below with authors' permission [63].

1. Complete DMEM-10 medium: Dulbecco's modified Eagle's medium, 10\% fetal bovine serum $(\mathrm{v} / \mathrm{v}), 2 \mathrm{mM}$ L-glutamine, $100 \mathrm{U} / \mathrm{mL}$ penicillin $\mathrm{G}, 100 \mu \mathrm{g} / \mathrm{mL}$ streptomycin.

2. $1000 \mathrm{U} / \mathrm{mL}$ human or mouse IL-9 reference standard.

3. Unknown samples containing IL-9.

4. TSI cell culture (3- to 4-day-old).

5. PBS, $\mathrm{pH} 7.4$.

6. $50 \mathrm{mM}$ citrate buffer, $\mathrm{pH}$ 5.0.

7. $0.25 \%$ Triton $\mathrm{X}-100$.

8. $3.75 \mathrm{mM} p$-nitrophenyl $N$-acetyl- $\beta$-D-glucosaminide.

9. Glycine buffer: $10 \mathrm{mM}$ EDTA, $0.1 \mathrm{M}$ glycine, $\mathrm{pH} 10.4$, store at room temperature.

10. Multichannel pipette and tips 
11. 96-well flat-bottom microtiter plates with lids.

12. $15 \mathrm{~mL}$ conical centrifuge tube

13. Jouan GR422 centrifuge (or equivalent).

\section{Methods}

\subsection{Measurement of IL-9 Activity Using the TS1h9RA3 Cell Proliferation Assay}

A basic protocol has been described by Jean-Christophe Renauld and Jacques Van Snick and included below with authors' permission [63].

1. Using a multichannel pipette, add $100 \mu \mathrm{L}$ of complete DMEM10 medium to each well of a 96-well flat-bottom microtiter plate.

2. Thaw the $1000 \mathrm{U} / \mathrm{mL}$ IL-9 standard and dilute with complete DMEM-10 medium to $600 \mathrm{U} / \mathrm{mL}$. Prepare serial dilutions of the IL-9 standard as follows:

(a) Add $50 \mu \mathrm{L}$ of $600 \mathrm{U} / \mathrm{mL}$ IL-9 to row A, columns $1-3$.

(b) Using a multichannel pipette, transfer $50 \mu \mathrm{L}$ from row $\mathrm{A}$, columns $1-3$, to the wells containing complete medium (from step $\mathbf{1}$ ) in row B, columns $1-3$.

(c) Mix the standard by pipetting up and down several times.

(d) Transfer $50 \mu \mathrm{L}$ from row $\mathrm{B}$, columns $1-3$, to row $\mathrm{C}$, columns $1-3$; mix thoroughly and continue this stepwise transfer of $50 \mu \mathrm{L}$ through row $\mathrm{G}$.

(e) When the last dilution is made in columns $1-3$ of row $G$, mix thoroughly and discard $50 \mu \mathrm{L}$ from these wells so that each well in columns $1-3$, rows A to $\mathrm{G}$, contains $100 \mu \mathrm{L}$ of medium plus standard.

3. Add $50 \mu \mathrm{L} /$ well of three unknown samples containing IL-9 in triplicate starting from row A, columns 4-6, 7-9, and 10-12. Repeat with another set of three samples in row E, columns 4-6, 7-9, and 10-12. Prepare three serial dilutions in rows $\mathrm{A}-\mathrm{D}$ and then in rows $\mathrm{E}-\mathrm{H}$ as described above in step 2 (to span a eightfold dilution range for each unknown sample).

4. Harvest TS1 cells from the tissue-culture flask in active logphase growth. Transfer the cells to a $15 \mathrm{~mL}$ conical centrifuge tube and centrifuge for $5 \mathrm{~min}$ at $300 \times g$ (1500 rpm in Jouan GR422 centrifuge), room temperature. Discard the supernatant and wash the cells at least two times in $14 \mathrm{~mL}$ of complete DMEM-10 medium to remove residual cytokine. Resuspend the cells in a small volume ( $1 \mathrm{~mL}$ ) of complete DMEM-10 medium. 
5. Count viable cells by the trypan blue exclusion method. Resuspend the cells at a concentration of $3 \times 10^{4}$ cells $/ \mathrm{mL}$ using complete DMEM-10 medium. Using a multichannel pipette, add $100 \mu \mathrm{L}$ of cell suspension to each well of the 96-well plate containing IL-9 standards or samples.

6. Cover the plate with a lid and incubate the plates for 3 days in a humidified $37^{\circ} \mathrm{C}, 5 \% \mathrm{CO}_{2}$ incubator.

7. After 3 days, wash cells two times with PBS, pH 7.4. To wash cells, centrifuge plates $5 \mathrm{~min}$ at $300 \times g$ at room temperature; discard supernatants and add $200 \mu \mathrm{L}$ of PBS per well. After the second wash, resuspend the cells in $60 \mu \mathrm{L}$ of $50 \mathrm{mM}$ citrate buffer containing $0.25 \%$ Triton $\mathrm{X}-100$ and $3.75 \mathrm{mM}$-nitrophenyl $\mathrm{N}$-acetyl- $\beta$-D-glucosaminide. Incubate for $1.5 \mathrm{~h}$ at $37^{\circ} \mathrm{C}$.

8. Stop the colorimetric reaction by adding $90 \mu \mathrm{L}$ of glycine buffer.

9. Quantify the IL-9 activity either directly or by comparison to a standard IL-9 sample. The concentration at which half-maximal effect is observed is defined as $1 \mathrm{U} / \mathrm{mL}$ of IL-9. With purified IL-9, $1 \mathrm{U} / \mathrm{mL}$ should correspond to $25 \mathrm{pg} / \mathrm{mL}$ for the mouse protein and $50 \mathrm{pg} / \mathrm{mL}$ for the human protein. Thus, the dilution factor required to obtain half-maximal proliferation with one particular sample corresponds to the number of $\mathrm{U} / \mathrm{mL}$ in this sample.

\subsection{Conclusion}

IL-9 is a multifaceted cytokine involved in multiple biological processes such as immune responses against parasites, pathogenesis of allergic diseases (bronchial asthma and hyperreactivity), and immunity against solid neoplasias. It is produced by several cells including mast cells, NKT cells, Th2, Th17, Treg, and ILC2 cells, but Th9 cells are the predominant producers of IL-9. Methods of detection include proliferation assays, ELISA for the detection in serum plasma and supernatant samples, and quantitative real-time PCR assay for relative expression in cells and tissues. Of these, ELISA and qPCR are established as the most suitable and widely used tools for IL-9 detection.

\section{Notes}

1. Due to the fact that there are no studies comparing performance between different ELISA kits, the decision on which one to use depends on the preference of the individual researcher.

2. From a practical standpoint, we would recommend the use of ELISA kits over the use proliferation assays to measure levels of IL-9. As previously mentioned, there are currently no studies comparing the performance of ELISA kits on the market between 
the commercial houses or comparison studies to proliferation assays. Despite the lack of evidence, there are various advantages of using the ELISA method. Cell cultures require more materials and frequent changing of culture medium. Despite these measures, the cells can still die or fail to grow properly.

3 . In the event the medium has a variety of other interleukins, there could be interference with measurement of IL-9. These competing interleukins would have to be blocked or removed from the culture medium before assessing the level of IL-9 in order to prevent false readings. In this scenario, the addition of antibodies against IL-9 is required to verify the modification of cellular proliferation. There could be proliferation despite the blocking of IL-9, and the addition of antibodies directed against other possible cytokines present would be required.

\section{References}

1. Noelle RJ, Nowak EC (2010) Cellular sources and immune functions of interleukin-9. Nat Rev Immunol 10(10):683-687. doi:10.1038/ nri2848

2. Renauld JC, Goethals A, Houssiau F, Van Roost E, Van Snick J (1990) Cloning and expression of a cDNA for the human homolog of mouse $\mathrm{T}$ cell and mast cell growth factor P40. Cytokine 2(1):9-12

3. Nicolaides NC, Holroyd KJ, Ewart SL, Eleff SM, Kiser MB, Dragwa CR, Sullivan CD, Grasso L, Zhang LY, Messler CJ, Zhou T, Kleeberger SR, Buetow KH, Levitt RC (1997) Interleukin 9: a candidate gene for asthma. Proc Natl Acad Sci U S A 94(24):13175-13180

4. Mock BA, Krall M, Kozak CA, Nesbitt MN, McBride OW, Renauld JC, Van Snick J (1990) IL9 maps to mouse chromosome 13 and human chromosome 5. Immunogenetics $31(4): 265-270$

5. Kaplan MH (2013) Th9 cells: differentiation and disease. Immunol Rev 252(1):104-115. doi:10.1111/imr.12028

6. Perumal NB, Kaplan MH (2011) Regulating IL-9 transcription in T helper cells. Trends Immunol 32(4):146-150. doi:10.1016/j. it.2011.01.006

7. Demoulin JB, Renauld JC (1998) Signalling by cytokines interacting with the interleukin-2 receptor gamma chain. Cytokines Cell Mol Ther 4(4):243-256

8. Knoops L, Renauld JC (2004) IL-9 and its receptor: from signal transduction to tumorigenesis. Growth Factors 22(4):207-215. doi:1 $0.1080 / 08977190410001720879$
9. Van Snick J, Goethals A, Renauld JC, Van Roost E, Uyttenhove C, Rubira MR, Moritz RL, Simpson RJ (1989) Cloning and characterization of a cDNA for a new mouse $\mathrm{T}$ cell growth factor (P40). J Exp Med 169(1):363-368

10. Uyttenhove C, Simpson RJ, Van Snick J (1988) Functional and structural characterization of P40, a mouse glycoprotein with T-cell growth factor activity. Proc Natl Acad Sci U S A 85(18):6934-6938

11. Schmitt E, Van Brandwijk R, Van Snick J, Siebold B, Rude E (1989) TCGF III/P40 is produced by naive murine CD4+ T cells but is not a general $\mathrm{T}$ cell growth factor. Eur J Immunol 19(11):2167-2170. doi:10.1002/ eji.1830191130

12. Stassen M, Schmitt E, Bopp T (2012) From interleukin-9 to $\mathrm{T}$ helper 9 cells. Ann N Y Acad Sci 1247:56-68. doi:10.1111/j.1749-6632.2011.06351.x

13. Schmitt E, Germann T, Goedert S, Hoehn P, Huels C, Koelsch S, Kuhn R, Muller W, Palm N, Rude E (1994) IL-9 production of naive CD4+ T cells depends on IL-2, is synergistically enhanced by a combination of TGF-beta and IL-4, and is inhibited by IFN-gamma. J Immunol 153(9):3989-3996

14. Veldhoen M, Uyttenhove C, van Snick J, Helmby H, Westendorf A, Buer J, Martin B, Wilhelm C, Stockinger B (2008) Transforming growth factor-beta 'reprograms' the differentiation of $\mathrm{T}$ helper 2 cells and promotes an interleukin 9-producing subset. Nat Immunol 9(12):1341-1346. doi:10.1038/ni.1659 
15. Dardalhon V, Awasthi A, Kwon H, Galileos G, Gao W, Sobel RA, Mitsdoerffer M, Strom TB, Elyaman W, Ho IC, Khoury S, Oukka M, Kuchroo VK (2008) IL-4 inhibits TGF-betainduced Foxp3 $+\mathrm{T}$ cells and, together with TGF-beta, generates IL-9+ IL-10+ Foxp3(-) effector T cells. Nat Immunol (12):13471355. doi:10.1038/ni.1677

16. Beriou G, Bradshaw EM, Lozano E, Costantino CM, Hastings WD, Orban T, Elyaman W, Khoury SJ, Kuchroo VK, BaecherAllan C, Hafler DA (2010) TGF-beta induces IL-9 production from human Thl7 cells. J Immunol 185(1):46-54. doi:10.4049/ jimmunol.1000356

17. Stassen M, Arnold M, Hultner L, Muller C, Neudorfl C, Reineke T, Schmitt E (2000) Murine bone marrow-derived mast cells as potent producers of IL-9: costimulatory function of IL-10 and kit ligand in the presence of IL-1. J Immunol 164(11):5549-5555

18. Lauwerys BR, Garot N, Renauld JC, Houssiau FA (2000) Cytokine production and killer activity of NK/T-NK cells derived with IL-2, IL-15, or the combination of IL-12 and IL-18. J Immunol 165(4):1847-1853

19. Nagato $T$, Kobayashi $H$, Kishibe $K$, Takahara M, Ogino T, Ishii H, Oikawa K, Aoki N, Sato K, Kimura S, Shimizu N, Tateno M, Harabuchi Y (2005) Expression of interleukin-9 in nasal natural killer/T-cell lymphoma cell lines and patients. Clin Cancer Res 11(23):8250-8257. doi:10.1158/1078-0432.ccr-05-1426

20. Houssiau FA, Renauld JC, Stevens M, Lehmann F, Lethe B, Coulie PG, Van Snick $\mathrm{J}$ (1993) Human $\mathrm{T}$ cell lines and clones respond to IL-9. J Immunol 150(7):2634-2640

21. Hultner L, Druez C, Moeller J, Uyttenhove C, Schmitt E, Rude E, Dormer P, Van Snick J (1990) Mast cell growth-enhancing activity (MEA) is structurally related and functionally identical to the novel mouse $T$ cell growth factor P40/TCGFIII (interleukin 9). Eur J Immunol 20(6):1413-1416. doi:10.1002/ eji.1830200632

22. Yang YC, Ricciardi S, Ciarletta A, Calvetti J, Kelleher K, Clark SC (1989) Expression cloning of cDNA encoding a novel human hematopoietic growth factor: human homologue of murine T-cell growth factor P40. Blood 74(6):1880-1884

23. Temann UA, Laouar Y, Eynon EE, Homer R, Flavell RA (2007) IL9 leads to airway inflammation by inducing IL13 expression in airway epithelial cells. Int Immunol 19(1):1-10. doi:10.1093/intimm/dxl117
24. Zhao P, Xiao X, Ghobrial RM, Li XC (2013) IL-9 and Th9 cells: progress and challenges. Int Immunol 25(10):547-551. doi:10.1093/ intimm/dxt039

25. Jones CP, Gregory LG, Causton B, Campbell GA, Lloyd CM (2012) Activin A and TGFbeta promote $\mathrm{T}(\mathrm{H}) 9$ cell-mediated pulmonary allergic pathology. J Allergy Clin Immunol 129(4):1000-1010.e1003. doi:10.1016/j. jaci.2011.12.965

26. Xing J, Wu Y, Ni B (2011) Th9: a new player in asthma pathogenesis? J Asthma 48(2):115125. doi:10.3109/02770903.2011.554944

27. Staudt V, Bothur E, Klein M, Lingnau K, Reuter S, Grebe N, Gerlitzki B, Hoffmann M, Ulges A, Taube C, Dehzad N, Becker M, Stassen M, Steinborn A, Lohoff M, Schild H, Schmitt E, Bopp T (2010) Interferon-regulatory factor 4 is essential for the developmental program of $\mathrm{T}$ helper 9 cells. Immunity 33(2):192-202. doi:10.1016/j.immuni.2010.07.014

28. Purwar R, Schlapbach C, Xiao S, Kang HS, Elyaman W, Jiang X, Jetten AM, Khoury SJ, Fuhlbrigge RC, Kuchroo VK, Clark RA, Kupper TS (2012) Robust tumor immunity to melanoma mediated by interleukin-9producing T cells. Nat Med 18(8):1248-1253. doi: $10.1038 / \mathrm{nm} .2856$

29. Faulkner H, Humphreys N, Renauld JC, Van Snick J, Grencis R (1997) Interleukin-9 is involved in host protective immunity to intestinal nematode infection. Eur J Immunol 27(10):25362540. doi:10.1002/eji.1830271011

30. Townsend JM, Fallon GP, Matthews JD, Smith P, Jolin EH, McKenzie NA (2000) IL-9-deficient mice establish fundamental roles for IL-9 in pulmonary mastocytosis and goblet cell hyperplasia but not T cell development. Immunity 13(4):573-583

31. Lu LF, Lind EF, Gondek DC, Bennett KA, Gleeson MW, Pino-Lagos K, Scott ZA, Coyle AJ, Reed JL, Van Snick J, Strom TB, Zheng XX, Noelle RJ (2006) Mast cells are essential intermediaries in regulatory $\mathrm{T}$-cell tolerance. Nature 442(7106):997-1002. doi:10.1038/ nature 05010

32. Yao W, Tepper RS, Kaplan MH (2011) Predisposition to the development of IL-9secreting $\mathrm{T}$ cells in atopic infants. J Allergy Clin Immunol 128(6):1357-1360.e1355. doi:10.1016/j.jaci.2011.06.019

33. Ouyang H, Shi Y, Liu Z, Feng S, Li L, Su N, Lu Y, Kong S (2013) Increased interleukin9 and CD4+IL-9+ T cells in patients with systemic lupus erythematosus. Mol Med Rep 7(3):10311037. doi:10.3892/mmr.2013.1258 
34. Dantas AT, Marques CD, da Rocha Junior LF, Cavalcanti MB, Goncalves SM, Cardoso PR, Mariz Hde A, Rego MJ, Duarte AL, Pitta Ida R, Pitta MG (2015) Increased serum interleukin-9 levels in rheumatoid arthritis and systemic lupus erythematosus: pathogenic role or just an epiphenomenon? Dis Markers 2015:519638. doi:10.1155/2015/519638

35. Ciccia F, Guggino G, Rizzo A, Manzo A, Vitolo B, La Manna MP, Giardina G, Sireci G, Dieli F, Montecucco CM, Alessandro R, Triolo G (2015) Potential involvement of IL-9 and Th9 cells in the pathogenesis of rheumatoid arthritis. Rheumatology (Oxford, UK). doi:10.1093/rheumatology/kev252

36. Yanaba K, Yoshizaki A, Asano Y, Kadono T, Sato S (2011) Serum interleukin 9 levels are increased in patients with systemic sclerosis: association with lower frequency and severity of pulmonary fibrosis. J Rheumatol 38(10):21932197. doi:10.3899/jrheum.110268

37. Pan HF, Leng RX, Li XP, Zheng SG, Ye DQ (2013) Targeting T-helper 9 cells and interleukin-9 in autoimmune diseases. Cytokine Growth Factor Rev 24(6):515-522

38. Rojas-Zuleta WG, Vásquez G (2016) Th9 lymphocytes: a recent history from IL-9 to its potential role in rheumatic diseases. Autoimmun Rev 15(7):649-655. doi:10.1016/j.autrev.2016.02.020

39. Gessner A, Blum H, Rollinghoff M (1993) Differential regulation of IL-9-expression after infection with leishmania major in susceptible and resistant mice. Immunobiology 189(5):419435. doi:10.1016/s0171-2985(11)80414-6

40. Chang HC, Sehra S, Goswami R, Yao W, Yu Q, Stritesky GL, Jabeen R, McKinley C, Ahyi AN, Han L, Nguyen ET, Robertson MJ, Perumal NB, Tepper RS, Nutt SL, Kaplan MH (2010) The transcription factor PU.1 is required for the development of IL-9-producing T cells and allergic inflammation. Nat Immunol 11(6):527-534. doi:10.1038/ni.1867

41. Monteiro M, Agua-Doce A, Almeida CF, Fonseca-Pereira D, Veiga-Fernandes H, Graca L (2015) IL-9 expression by invariant NKT cells is not imprinted during thymic development. J Immunol 195(7):3463-3471. doi:10.4049/jimmunol.1403170

42. Jones TG, Hallgren J, Humbles A, Burwell T, Finkelman FD, Alcaide P, Austen KF, Gurish MF (2009) Antigen-induced increases in pulmonary mast cell progenitor numbers depend on IL-9 and CDld-restricted NKT cells. J Immunol 183(8):5251-5260. doi:10.4049/ jimmunol.0901471

43. Wiener Z, Falus A, Toth S (2004) IL-9 increases the expression of several cytokines in activated mast cells, while the IL-9-induced IL-9 production is inhibited in mast cells of histamine-free transgenic mice. Cytokine 26(3):122-130. doi:10.1016/j.cyto.2004.01.006

44. Stassen M, Klein M, Becker M, Bopp T, Neudorfl C, Richter C, Heib V, KleinHessling S, Serfling E, Schild H, Schmitt E (2007) p38 MAP kinase drives the expression of mast cell-derived IL-9 via activation of the transcription factor GATA-1. Mol Immunol 44(5):926-933. doi:10.1016/j. molimm.2006.03.019

45. Chen C-Y, Lee J-B, Liu B, Ohta S, Wang P-Y, Kartashov Andrey V, Mugge L, Abonia JP, Barski A, Izuhara K, Rothenberg Marc E, Finkelman Fred D, Hogan Simon P, Wang Y-H (2015) Induction of interleukin-9-producing mucosal mast cells promotes susceptibility to IgE-mediated experimental food allergy. Immunity 43(4):788-802. doi:10.1016/j. immuni.2015.08.020

46. Szabo SJ, Kim ST, Costa GL, Zhang X, Fathman CG, Glimcher LH (2000) A novel transcription factor, T-bet, directs Thl lineage commitment. Cell 100(6):655-669

47. Zheng W, Flavell RA (1997) The transcription factor GATA-3 is necessary and sufficient for Th2 cytokine gene expression in CD4 T cells. Cell 89(4):587-596

48. Hori S, Nomura T, Sakaguchi S (2003) Control of regulatory $\mathrm{T}$ cell development by the transcription factor Foxp3. Science (New York, NY) 299(5609):1057-1061. doi:10.1126/ science. 1079490

49. Ivanov II, McKenzie BS, Zhou L, Tadokoro CE, Lepelley A, Lafaille JJ, Cua DJ, Littman DR (2006) The orphan nuclear receptor RORgammat directs the differentiation program of proinflammatory IL-17+ T helper cells. Cell 126(6):1121-1133. doi:10.1016/j. cell.2006.07.035

50. Angkasekwinai $\mathrm{P}$, Chang SH, Thapa M, Watarai H, Dong C (2010) Regulation of IL-9 expression by IL-25 signaling. Nat Immunol $11(3): 250-256$. doi:10.1038/ni.1846

51. Mikami N, Miyagi Y, Sueda K, Takatsuji M, Fukada S, Yamamoto H, Tsujikawa K (2013) Calcitonin gene-related peptide and cyclic adenosine 5'-monophosphate/protein kinase A pathway promote IL-9 production in Th9 differentiation process. J Immunol 190(8):40464055. doi:10.4049/jimmunol.1203102

52. Yao W, Zhang Y, Jabeen R, Nguyen ET, Wilkes DS, Tepper RS, Kaplan MH, Zhou B (2013) Interleukin-9 is required for allergic airway inflammation mediated by the cytokine TSLP. Immunity 38(2):360-372. doi:10.1016/j. immuni.2013.01.007 
53. Elyaman W, Bradshaw EM, Uyttenhove C, Dardalhon V, Awasthi A, Imitola J, Bettelli E, Oukka M, van Snick J, Renauld JC, Kuchroo VK, Khoury SJ (2009) IL-9 induces differentiation of TH17 cells and enhances function of FoxP3+ natural regulatory T cells. Proc Natl Acad Sci U S A 106(31):12885-12890. doi:10.1073/pnas.0812530106

54. Liu Y, Teige I, Birnir B, Issazadeh-Navikas S (2006) Neuron-mediated generation of regulatory $\mathrm{T}$ cells from encephalitogenic $\mathrm{T}$ cells suppresses EAE. Nat Med 12(5):518-525. doi:10.1038/nml402

55. Roediger B, Weninger W (2015) Group 2 innate lymphoid cells in the regulation of immune responses. Adv Immunol 125:111154. doi:10.1016/bs.ai.2014.09.004

56. Wilhelm C, Hirota K, Stieglitz B, Van Snick J, Tolaini M, Lahl K, Sparwasser T, Helmby H, Stockinger B (2011) An IL-9 fate reporter demonstrates the induction of an innate IL-9 response in lung inflammation. Nat Immunol 12(11):1071-1077. doi:10.1038/ni.2133

57. Wilhelm C, Turner JE, Van Snick J, Stockinger B (2012) The many lives of IL-9: a question of survival? Nat Immunol 13(7):637-641. doi: $10.1038 /$ ni. 2303

58. Spits H, Di Santo JP (2011) The expanding family of innate lymphoid cells: regulators and effectors of immunity and tissue remodeling. Nat Immunol 12(1):21-27. doi:10.1038/ni.1962

59. Turner JE, Morrison PJ, Wilhelm C, Wilson M, Ahlfors H, Renauld JC, Panzer U, Helmby H, Stockinger B (2013) IL-9-mediated survival of type 2 innate lymphoid cells promotes damage control in helminth-induced lung inflammation. J Exp Med 210(13):29512965. doi:10.1084/jem.20130071

60. Stordeur P, Poulin LF, Craciun L, Zhou L, Schandene L, de Lavareille A, Goriely S, Goldman M (2002) Cytokine mRNA quantification by real-time PCR. J Immunol Methods 259(1-2):55-64

61. Kubista M, Andrade JM, Bengtsson M, Forootan A, Jonak J, Lind K, Sindelka R, Sjoback R, Sjogreen B, Strombom L, Stahlberg A, Zoric N (2006) The real-time polymerase chain reaction. Mol Aspects Med 27(2-3):95125. doi:10.1016/j.mam.2005.12.007

62. Livak KJ, Schmittgen TD (2001) Analysis of relative gene expression data using real-time quantitative PCR and the $2(-$ Delta Delta $\mathrm{C}(\mathrm{T})$ ) Method. Methods (San Diego, CA) 25(4):402408. doi:10.1006/meth.2001.1262

63. Renauld JC, Van Snick J (2002) Measurement of mouse and human interleukin 9. Curr Protoc Immunol Chapter 6:Unit 6.13. doi:10.1002/0471142735.im0613s51

64. Shevach EM (2001) Labeling cells in microtiter plates for determination of $[3 \mathrm{H}]$ thymidine uptake. Curr Protoc Immunol Appendix 3:Appendix 3D. doi:10.1002/0471142735. ima03ds21

65. Avanzi GC, Brizzi MF, Giannotti J, Ciarletta A, Yang YC, Pegoraro L, Clark SC (1990) $\mathrm{M}-07 \mathrm{e}$ human leukemic factor-dependent cell line provides a rapid and sensitive bioassay for the human cytokines GM-CSF and IL-3. J Cell Physiol 145(3):458-464. doi:10.1002/ jсp. 1041450310 